\title{
Role of Intellectual Capital and Work Behavior in Supporting Lecturer's Performance
}

\author{
Abd. Rahman Rahim ${ }^{1}$, Edi Jusriadi ${ }^{1} \&$ Ruliaty $^{1}$ \\ 1 Economic Management Department, Universitas Muhammadiyah Makassar, South Sulawesi, Indonesia \\ Correspondence: Abd. Rahman Rahim, Economic Management Department, Universitas Muhammadiyah \\ Makassar, South Sulawesi, Indonesia. E-mail: rahman.rahim@unismuh.ac.id
}

Received: April 18, 2017

Accepted: April 28, 2017

Online Published: August 2, 2017

doi:10.5539/res.v9n3p117

URL: http://doi.org/10.5539/res.v9n3p117

\begin{abstract}
Muhammadiyah Universities in South Sulawesi face the challenges of competitiveness, quality of human resources and lecturer's on Tridharma performance in the field of education and teaching, research and scientific publications, and dedication to the community and other support activities.

This research aims at reconstructing the development of intellectual capital through Al-Islam Kemuhammadiyaan values approach. So as to create good work behavior in order to support the university's performance on Tridharma.

This research is a quantitative research with positivist approach. The research design used in quantitative research is an explanatory research using survey methods at 10 Muhammadiyah universities in South Sulawesi by distributing questionnaires to 154 lecturers, but that can be processed only 146 questionnaires. Primary data were then analyzed using Structural Equations Models (SEM) techniques and the program is Analysis of Moment Structure (AMOS).

The research findings are: (1) intellectual capital contribute significantly in supporting the lecturer's work behavior of Muhammadiyah Universities in South Sulawesi. (2) intellectual capital does not contribute significantly in supporting the lecturer's Tridharma performance of Muhammadiyah Universities in South Sulawesi. (3) work behavior contribute significantly in supporting lecturer's performance of Muhammadiyah Universities in South Sulawesi.
\end{abstract}

Keywords: intellectual capital, Al-Islam Kemuhammadiyaan, work behavior, performance

\section{Introduction}

Job performance in Human Resource Development (HRD) perspective either in the form of task performance and contextual performance in its achievement need support of intellectual capital and work behavior, Borman and Motowidlo 1993 (Kaswan, 2015, pp. 156-160). According to the Resource Based Theory (RBT) on Wernerfelt (1984) and Barney (1991) that in era of knowledge and information technology-based economy, the requirement of improving the quality, effectiveness, and efficiency depends not only on the availability of physical capital and financial capital, but it really depends on the role of human capital (Nothnagel, 2008). Thus Johanson et al. (1999) state that competitiveness based on technology is only temporary, while the sustainable advantages is rely on the development of intellectual capital the human capital and organizational capabilities create added value (Lev, 2001; Sveiby, 2001; Hurwitz et al., 2002).

Muhammadiyah Universities in South Sulawesi face the challenge of competitiveness, the quality of human resources, and the lecturer's Tridharma performance. Strategies to improve the competitive advantage in the practice of Human Resource Development (HRD) can be done through the development of intellectual capital and good work behavior (Alwi, 2001; Ulrich, 1997; Stewart, 1998). The development of intellectual capital in view of Swanson and Holton (2001) and Stoner (2005) can be done through a process of training and development that is based on the values of Al-Islam Kemuhammadiyaan. Internally, development model of intellectual capital and work behavior can be done by Muhammadiyah Universities in improving the lecturer's performance through this process, namely: (1) formal education (further studies), (2) non-formal education (training), and (3) education of Al-Islam Kemuhammadiyaan values (Baitul Arqam). This process aims at improving the lecturer's competence, both pedagogical competence, professional competence, social competence, and personal competence, as a 
fundamental competence in performing the caturdharma tasks of lecturer in the form of education and teaching, research and scientific publications, community service activities, and other supporting activities and Al-Islam Kemuhammadiyaan practice (Act No. 14 of 2005).

Admittedly intellectual capital as an asset of the organization's future (PSK/SAK revised 2010), it provides the important space of the research related intangible assets, especially in universities which have the function to produce knowledge, research and development of human resource. Research that developed since the 19th century more study about the size of organizational performance than the aspects of tangible assets. Then in the 20th century, along with a shift in the type of society from industrial society to the knowledge society and the paradigm shift related accounting reporting system of the organization's resources from the Stewardship system to current value provides space to develop the research about performance measurement systems from intellectual capital aspects. Nevertheless, the existence of intellectual capital as a measure of performance is still debatable, so Ulrich (1998); Burr and Girardi (2002) provide an alternative measurement of intellectual capital by looking at the characteristics of intellectual capital of the human capital, namely: (1) the level of competence, (2) organizational commitment, and (3) work controlling, which can be formulated as follows:

\subsection{Intellectual Capital=Competence $x$ Organizational Commitment $x$ Work Controlling}

The practice of measuring intellectual capital carried Ulrich (1998); Burr and Girardi (2002), also supported by the results of research conducted by Bezhani (2010), at 30 universities in the UK. The study found that the practice of measuring intellectual capital in the annual report at 30 Universities in the UK are still low. Research of measuring intellectual capital was also conducted in Indonesia at three universities, namely: UGM, UI, and ITB (webomatrics ranking) by Puspitahati et al. (2011). The study found that the measurement of intellectual capital at universities in Indonesia is still low. The low result of measurement of intellectual capital at universities in Europe and Indonesia became one of the considerations in addition to the competitiveness of the institution (accreditation), quality of human resources (knowledge, skills, attitude), and lecturer's caturdharma performance for further investigation related to the size of performance of the intangible assets (intellectual capital).

Some research that supports and explains the phenomenon at Muhammadiyah universities such as Sairin's articles (2009), which states that Muhammadiyah had been neglected the professionalism to develop itself in achieving organizational goals. Furthermore, Rais (1997) states that there are five (5) critical flaws in Muhammadiyah, namely: (1) weakness of leadership, (2) weakness of the cadre, (3) weakness of the organization, (4) weakness of the conceptual, and (5) weakness of mass-media. Meanwhile, Boerhani (2002) states that the weakness of Muhammadiyah is also the professionalism which are caused by the governance system of Muhammadiyah Universities and behavior of employees, where professionalism is not yet a work culture. Results of Rahim's research (2012) also found that the level of employees welfare at the Islamic University in South Sulawesi is still low. Meanwhile, the contribution of intellectual capital can support the performance reinforced by the results of research conducted by Zomorrodian (2014); Sen, Zhou et al. (2014); Spahic (2014); Yung Chieh (2013); and Stevens (2012).

\subsection{Research Model and Development of Research Hypothesis}

Taxonomy of intellectual assets, intellectual capital, and intangible assets are often used interchangeably in academic discourse (Ali et al., 2010). Similarly, the term knowledge assets is often used by economists and management experts that call it as intellectual capital (Brooking, 1997; Stewart, 1997), while the accountants more often use the word intangible assets (Kavida \& Sivakoumar, 2008). Another term often used, namely: invisible assets (Itami, 1991), immaterial values (Sveiby, 2001), and Intangibles (Lev, 2001).

This study uses the term intellectual capital to describe an intangible asset. Intellectual capital emphasizes the combination of intellectuality and capital to demonstrate the importance of knowledge (Serenko \& Bontis, 2013). Stewart (1997) states that intellectual capital is intellectual material in the form of knowledge, skills, work behavior, information, intellectual rights, and experiences are used to create wealth. While Smedlund and Poyhonen (2005); Rupidara (2005) (in Solikhah et al., 2010) state that the intellectual capital as the capabilities of individuals to create, transfer, and implement knowledge.

Intellectual capital in this research is the ability or competence of lecturers in the form of pedagogical competence, professional competence, social competence, and personal competence that can be used in carrying out the caturdharma. Spencer, M. L. and Spencer, M. S. (1993) states that competence is something underlying individual characteristics such as: (1) the motives, which is something that is consistently considered the cause of action, (2) the character or nature (traits), namely: the physical characteristics and a consistent response to the situation and information, (3) self-concept, is the attitude, values, or self-image. Self-confidence is the assurance that their votes 
can be effective in every situation, (4) Knowledge, is information that people have in their specific field and (5) skills, that is the ability to do the physical task or specific mental abilities.

Some research found that academic competence has significant and positive impact on the performance of individuals, such as the results of research conducted Dharma (in Sutrisno, 2011) which found that learning achievement (GPA) can predict the performance of individuals. In her research, Lestari As (2014) also found that there are positive and significant relationship between the competence of lecturers with the performance of lecturers. Similarly, research conducted Muhammad Rushd (2014) found that competence has significant impact on the performance of foreign lecturers in Colleges. Meanwhile, related to the contribution of intellectual capital in supporting the work behavior has been demonstrated on several studies which found that religion competence has significant and positive impact on the formation of work behaviors, such as Weber's research (Ancok, 1994) which examines the relationship between work ethic with religion. The results of his research found that religion competence was able to establish and improve the work force and motivation toward the real being, it means that there is a direct relationship between the value system of a religion with the excitement of working in individual. Hermawan's research (2012) also found that the improvement of pharmaceutical industry business practices can be done with the management of ethics and moral (behavioral crimes)-based employee's intellectual capital and the support of stakeholders. Results of Yung-Chieh-Chien's research (2013) found that the accumulation of intellectual capital has significant and positive impact on employee's work behavior biotech company in Taiwan. The research was supported by Suliswiyadi's opinion (2011), says that religion education can form a good moral or good manners. The contributions of work behavior in supporting the performance is also explained by Steers (1985, p. 152) and Ivancevich et al. (2006, p. 85) which state that the work behavior can be influenced by two factors, namely: first, internal factors such as intrinsic motivation, attributes and feelings of individual; second, external factors such as organizational support and academic atmosphere. So that Robbins (2003) explains that the difference of individuals performance in organization due to the differences of work behavior in the form of: (1) motivation, (2) individual's attributes, and (3) work environment. Several studies show that a good work behavior can improve the performance as Yung-Chieh Chien (2013) found that the verification of business practices in listed biotechnology company in Taiwan, interaction between the accumulation of healthy intellectual capital and citizens behavior of organizations (OCB) influences the organizational performance of listed biotechnology company in Taiwan positively and significantly. Similarly, results of research by Muhdar HM (2014) found that work behavior which is manifested in the form of Organizational Citizenship Behavior (OCB) has positive and significant impact on employees's performance of Islamic Banks in Makassar. Based on the theoretical description and review studies, the research hypotheses are:

1) Intellectual capital contributes significantly in supporting the lecturer's work behavior of Muhammadiyah Universities in South Sulawesi.

2) Intellectual capital contributes significantly in supporting the lecturer's performance of Muhammadiyah Universities in South Sulawesi.

3) Work behavior contributes significantly in supporting the lecturer's performance of Muhammadiyah Universities in South Sulawesi.

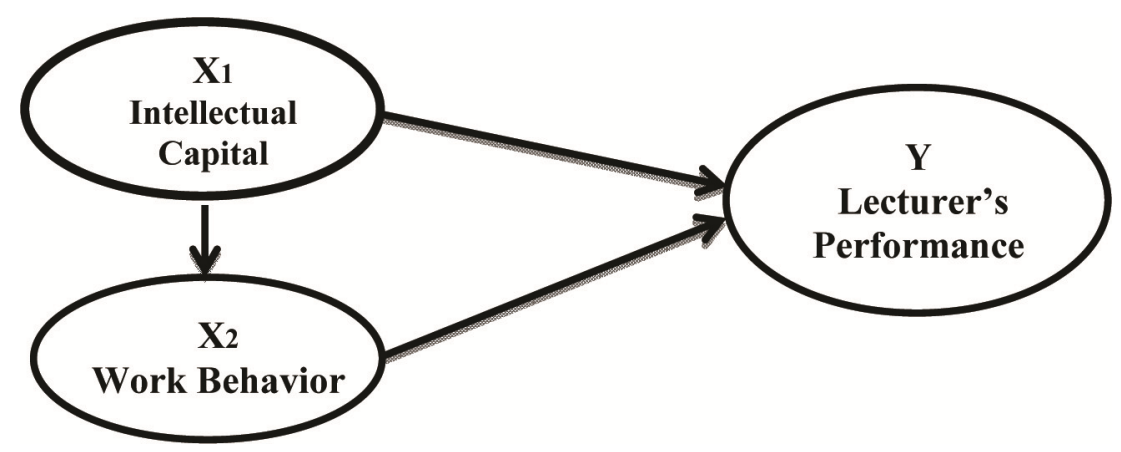

Figure 1. Conceptual framework 


\section{Methodology}

\section{Research Type and Research Design}

This research is a quantitative research with positivist approach, while research designs used in this quantitative research is explanatory research. This study uses a survey method at 10 Muhammadiyah Universities in South Sulawesi by giving questionnaires to 154 lecturers. Primary data were then analyzed using Structural Equations Models (SEM) techniques and the program used is Analysis of Moment Structure (AMOS) version 21.0.

\section{Research Finding and Discussion}

\subsection{Results Descriptive Analysis Research}

Research variable described in this study is latent variables by interpreting the average value of each indicator in order to provide an explanation of any indicators that establish the concept or model of the overall study. Basic of interpretation about the average value used in this study refers to the interpretation of score used by Steven, Jr. (2004), which can be explained in the following table:

Table 1. The average value of Respondent's Answering per indicator of variables






\begin{tabular}{|c|c|c|c|c|}
\hline $\mathrm{X} 2.1$ & Motivation/Effort & 4,04 & 80,8 & Important \\
\hline $\mathrm{X} 2.2$ & Individual attributes & 3,86 & 77,2 & Important \\
\hline $\mathrm{X} 2.3$ & Work Environment & 4,15 & 83 & Important \\
\hline & of Work Behavior Variable & 4,01 & 80,2 & Important \\
\hline \multicolumn{4}{|c|}{ Y: Lecturer's Tridharma Performance } & \multirow{2}{*}{ Assesment } \\
\hline Category & Indicator & Mean & $\%$ & \\
\hline Y1.1 & Education and Teaching & 3,96 & 79,2 & Good \\
\hline $\mathrm{Y} 1.2$ & Research and Scientific Publication & 3,25 & 65 & Good Enough \\
\hline Y1.3 & $\begin{array}{c}\text { Community Service and Other Supporting } \\
\text { Activities }\end{array}$ & 3,40 & 68 & Good Enough \\
\hline \multicolumn{2}{|c|}{ Mean of Lecturer's Tridharma Performance Variable } & 3,53 & 70,6 & Good \\
\hline
\end{tabular}

Source: Appendix 3 Frequency Distribution of Research Indicators.

Based on the results of descriptive analysis showed that the lecturers of Muhammadiyah Universities in South Sulawesi gave an assesment to intellectual capital variable as a very important category with a mean value is 4.17 or $83.4 \%$; work behavior as an important category with a mean value is 4.01 or $80.2 \%$; and a performance of lecturers variable as a good category with a mean value is 3.53 or $70.6 \%$.

\subsection{The Results of Inferential Statistical Analysis}

Based on the empirical model proposed in this study, we can test the hypothesis proposed through testing the path coefficients in a structural equation model as follows:

Table 2. Results of hypothesis testing

\begin{tabular}{|c|c|c|c|c|c|c|}
\hline \multirow{2}{*}{ Hypothesis } & \multirow{2}{*}{ Independent Variables } & \multirow{2}{*}{$\begin{array}{c}\text { Dependent } \\
\text { Variables }\end{array}$} & \multicolumn{3}{|c|}{ Direct Effect } & \multirow{2}{*}{ Information } \\
\hline & & & Standardize & CR & p-value & \\
\hline $\mathrm{H} 1$ & Intellectual Capital & Work Behavior & 0,507 & 4,411 & 0,000 & Significant \\
\hline $\mathrm{H} 2$ & Intellectual Capital & Performance & 0,360 & 1,798 & 0,072 & Not Significant \\
\hline $\mathrm{H} 3$ & Work Behavior & Performance & 0,507 & 2,448 & 0,014 & Significant \\
\hline \multicolumn{7}{|c|}{ Indirect Effect } \\
\hline Ind & endent Variables & $\begin{array}{c}\text { Dependent } \\
\text { Variables }\end{array}$ & $\begin{array}{c}\text { Intervening } \\
\text { Variables }\end{array}$ & \multicolumn{2}{|c|}{ Standardize } & Information \\
\hline \multicolumn{2}{|c|}{ Intellectual Capital } & Performance & Work Behavior & \multicolumn{2}{|c|}{0,257} & Significant \\
\hline
\end{tabular}

Source: Appendix 6: Testing of Research Model, Processed in 2016.

Analysis the results of research model testing based on hypothesis can be explained as follows:

H1: Intellectual capital contributes positively and significantly in supporting the lecturer's work behavior with $\mathrm{p}$-value $=0.000<0.05$ and the contribution value is $50.7 \%$. It means that getting better intellectual capital then lecturer's work behavior will be more significant.

H2: Intellectual capital contributes positively but significantly in supporting the lecturer's performance with $p$-value $=0.072>0.05$ and the contribution value is $36 \%$. It means that the intellectual capital level of a lecturer can not directly improve his or her performance. However, intellectual capital can contributes in supporting lecturer's performance when it is mediated by work behavior variable.

H3: Work behavior contributes positively and significantly in supporting the lecturer's performance with $\mathrm{p}$-value $=0.014<0.05$ and the contribution value is $50.7 \%$. It means that the better work behavior of a lecturer then lecturer's performance will increase. 


\section{Research Findings}

The empirical and theoretical findings in this study is expected to have implications for the development of the theory of Human Resource Development (HRD) that is an intangible asset. The influence of intellectual capital in supporting the work behavior and performance has been widely proven, both theoretically and empirically. A new thing in this study is education of Al-Islam Kemuhammadiyaan values as one effort to develop intellectual capital that is softskill which has not been theoretically and empirically proven. The importance of intellectual capital development through education and training is also affirmed in the Qur'an Surah Al-Mujaadilah paragraph 11, which means "... Allah will lift (degrees) those who believe among you and those who have knowledge in some levels".

But in this study found that intellectual capital has no significant effect on performance. Intellectual capital can have a significant effect on performance when it is mediated by good work behaviors. It means that the better level of understanding and practice of the Al-Islam Kemuhammadiyaan values then the work behaviors will be more significant that it would have implications for the improvement of lecturer's performance of Muhammadiyah Universities in South Sulawesi.

\section{Implications for Research}

\subsection{Theoretical Implications}

The findings of this study theoretically provide affirmative the importance of Human Resource Development (HRD). So, according to the Resource-Based Theory (RBT) that intellectual capital can be used as a performance measure in this study was not proven, but intellectual capital can contribute to improve the performance of lecturer's Tridharma when it is mediated by good work behavior through the understanding and practice of the Al-Islam Kemuhammadiyaan values in carrying out duties as a professional educator.

The findings of this study also provide debating affirmation whether intellectual capital can be or cannot be recognized as an asset that can be used as a measure of performance (PSK 19, revised 2010). The results of this study complements findings by Ulrich (1998); Burr and Girardi (2002) that the intellectual capital can be recognized as an asset that can be used as a measure of performance. Further, according to Sveiby (2001); FASB (1980), intellectual capital can be an asset if it can provide economic benefits or outcome of the process of training and development in the form of changes in work behavior and performance.

\subsection{Practical Implications}

Performance development model through the development of intellectual capital in the form of hardskills and sofskill can be used as role models in managing universities and private organizations that provide services to the community.

\section{Conclusion}

1) Intellectual capital contributes positively and significantly to the lecturer's work behavior of Muhammadiyah Universities in South Sulawesi.

2) Intellectual capital does not contribute significantly to the lecturer's performance of Muhammadiyah Universities in South Sulawesi.

3) Work behavior has positive and significant impact on the lecture's performance of Muhammadiyah Universities in South Sulawesi.

\section{Suggestions/Recommendations}

1) The development of intellectual capital needs to be taken together as a part of the organization's investment in long term. Therefore, it needs political will and policy from the leader of Muhammadiyah University in South Sulawesi.

2) The results of this research showed there are many variables that can affect the development of intellectual capital that needs to be investigated. Researchers suggest for the further research in order to do research on the same object and add some independent or dependent variables contributing to the improvement of performance, such as: diversity, empowerment, Islamic leadership, and prosperity. This research could also be developed to compare the governance and performance of lecturers between Muhammadiyah Universities with other public or private universities. 


\section{Reference}

Ali, I. M., Rahim, N. A., Shukor, S. S. A., \& Rashid, H. M. A. (2010). The Relationship Between Intangble Assets and Firm Value. Artikel dipresentasikan pada International Conference on Busisness and Economic Research, 15-16 Maret 2010 di Kuching, Sarawak, Malaysia.

Alwi, S. (2001). Manajemen Sumber Daya Manusia: Strategi Keunggulan Kompetitif(Y. Pertama, Ed.). BPFE.

Ancok, J. (1994). Psikologi Islam. Yogyakarta: Pustaka Pelajar.

Barney, J. (1991). Firm Resources and Sustained Competitive Advantage. Journal of Management, 17(1). https://doi.org/10.1177/014920639101700108

Benzhani, I. (2010). Intellectual Capital Reporting at UK Universities. Journal of intellectual capital, 11(2), 179-207. https://doi.org/10.1108/14691931011039679

Boerhani. (2002). Hubungan kepemimpinan, iklim organisasi dan motivasi dengan prestasi kerja karyawan UMS. Semarang: Jurnal Universitas Diponegoro.

Brooking, A. (1997). Intellectual Capital. London: International Thompson Business Press.

Burr, R., \& Antonia, G. (2002). Intellectual Capital: More Than The Interaction of Competence x Commitment. Journal of Management, 77-78. https://doi.org/10.1177/031289620202701s09

Chien, Y. C. (2013). The Effects of Organizational Performance on the Intellectual Capital Accumulation of Taiwan-listed Biotechnology Companies: Organizational Citizen Behavior as a Moderator. The Journal of Human Resource and Adult Learning, 9(1), 40-54.

Departemen Agama Republik Indonesia. (2005). Al-Qur"an dan Terjemahnya. Jakarta: PT Syamil Cipta Media.

Financial Accounting Standard Board (FASB). (1980). Qualitative Characteristics of Accounting Information. FASB, SFAC No. 2.

Hermawan, S. (2012). Peran, Pengelolaan, dan Pemberdayaan Intellectual Capital, Serta Perbaikan Praktik Bisnis Industri Farmasi. Disertasi, Pascasarjana Fakultas Ekonomi dan Bisnis, Universitas Airlangga Surabaya.

Hurwitz, J., Lines, S., Montgomery, B., \& Schmidt, J. (2002). The Linkage Between Management Practice, Intangible Performance and Stock Returns. Journal of Intellectual Capital, 3(1), 51-61. https://doi.org/10.1108/14691930210412845

Itami, H. (1991). Mobilizing Invisible Assets. Cambridge, MA: Harvard University Press.

Ivancevich, J. M. (2006). Human Resource Management (8th ed.). McGraw Hill, New York.

Johanson, U., Martenson, M., \& Skoog, M. (1999). Measuring and Managing Intangibles, Eleven Swedish Qualitative Exploratory Case Studis. Artikel dipresentasikan pada Accounting for Intangible and the Virtual Organization, Februari, Brussels.

Kaswan dan Ade Sadikin, A. (2015). Pengembangan Sumber Daya Manusia: Dari Konsepsi, Paradigma, dan Fungsi Sampai Aplikasi, Cet-1. Bandung: Alfabeta.

Kavida, V., \& Sivakourmar, N. (2008). Corporate Governance in Knowledge Economy the Relevance of Intellectual Capital. https://doi.org/10.2139/ssrn.1152892

Lestari, A. S., \& Dirga. (2014). Determinan Pengembangan Karier Dosen Pada Perguruan Tinggi Di Samarinda (Disertation not be published). Makassar: Pascasarjana Universitas Hasanuddin.

Lev, B. (2001). Intangible: Management, Measurement, and Reporting. Washington: The Brooking Institution.

Muhdar, H. M. (2014). Kecerdasan Spritual, Kepemimpinan, Budaya Organisasi Pengaruhnya Terhadap Organizational Citizenship Behavior Dan Kinerja Karyawan Pada Bank Umum Syariah Di Kota Makassar (Disertation). Makassar: Pascasarjana Universitas Hasanuddin.

Nothnagel, K. (2008). Empirical Research Within Resource Based Theory: A Meta Analysis of the Central Propositions. Germany: Gabler.

Puspitahati, A., Ulum, I., \& Prasetyo, A. (2011). Analisis Pengungkapan Intellectual Capital pada Website Tiga Perguruan Tinggi di Indonesia. Proceeding Seminar Nasional \& Call for Paper FE Univ. Muhammadiyah Sidoarjo, 19 Pebruari 2011. 
Rahim, R. A. (2012). Pengaruh Penerapan Kepemimpinan Islami terhadap Keadilan Distributif dan Kesejahteraan Karyawan di Perguruan Tinggi Islama Sulawesi Selatan (Disertasi). Surabaya: Pascasarjana Universitas Airlangga.

Rais, A. (1997). Visi dan Misi Muhammadiyah. In Mitra grafika pustaka suara Muhammadiyah (1st ed.). Yogyakarta.

Robbins, S. P. (2003). Perilaku Oragnisasi, Konsep, Kontroversi, dan Aplikasi. Edisi Bahasa Indonesia. Jakarta: Salemba Empat.

Rusydi, M. (2014). The Effect Leadership and Empowerment on competence and job performance lecturer the IX Region Kopertis in Macassar city (Disertasi). Makassar: Pascasarjana Universitas Hasanuddin.

Sairin, S. et al. (2009). Profesionalisme dan Etos Kerja. Yogyakarta: LPPT Muhammadiyah Pusat.

Sen, Z. et al. (2014). How Intellectual Capital Reduces Stress on Organizational Decision Making Performance: The Mediating Roles of Task Complexity and Time Pressure, Proceedings of the 11th International ISCRAM Conference-University Park, Pennsylvania (S. R. Hiltz, M. S. Pfaff, L. Plotnick, \& P. C. Shih, Eds., pp. 220-224).

Serenko, A., \& Bontis, N. (2013). The intellectual core and impact of the knowledge management academic discipline. Journal of Knowledge $\quad$ Management, $137-155$. https://doi.org/10.1108/13673271311300840

Solikhah, B. et al. (2010). Implikasi Intellectual Capital terhadap Financial Performance, Growth and Market Value: Studi Empiris dengan Pendekatan Simlistic Specifiestion. In Simposium Nasional Akuntansi (SNA) XIII. Pontianak.

Spahic, E. (2014). Models for measurement of national intellectual capital-A case study of the skandia navigator model. In Economic and Social Development (pp. 152-166). 7th International Scientific Conference, New York City.

Spencer, M. L., \& Spencer, M. S. (1993). Competence at Work: Models for Superrior Performance. New York, USA: John Wily \& Son, Inc.

Steers, M. R., \& Porter, W. (1985). Motivation and Work Behavior (5th ed.). Singapore: MC. Graw Hill.

Steven, Jr. (2004). Apllied multivariate Statistics for the social sciences (4th ed.). Hillsdale, NJ: Lawrence Erlbau Publishing.

Stevens, R. H. (2012). Comparison and Association of Intellectual Capital: An Investigation and Measurement of the Value of Intellectual Capital Assets and their Contribution to Stakeholder Perception Within the Framework of Higher Education (Disertation publishing). UMI 3491610.

Stewart, T. A. (1997). Intellectual Capital the New Wealth of Organization. London: Nicholas Brealey.

Stewart, T. A. (1998). Intellectual Capital: Kekayaan Baru Organisasi. Alih Bahasa: Reza Gunawan, Jakarta: PT Alex Media Komputindo.

Stoner, J. (2005). Manajemen. Jakarta: Prenhalindo.

Suliswiyadi. (2011). Pengembangan Nilai Keberagamaan Pada Pendidikan Agama Di SLTA Muhammadiyah Kabupaten Magelang (Disertasi Tidak Dipublikasikan). UIN Sunan Kalijaga Yogyakarta.

Sutrisno, E. (2011). Manajemen Sumber Daya Manusia. Edisi Pertama, Jakarta: Kencana Prenada Media Group.

Sveiby, K. E. (2001). A Knowledge-Based-Theory of the Firm to Guide in Startegy Formulation. Journal of Intellectual Capital, 2(4), 344-358. https://doi.org/10.1108/14691930110409651

Swanson, R. A., \& Elwood, F. H. (2001). Foundations of Human Resource Development. San Francisco: Berrett-Koehler Publisher, Inc (BK).

Ulrich, D. (1997). Human Resouce Champions. Boston: Harvard Business School Press, Wright.

Ulrich, D. (1998). Intellectual Capital=Competence x Commitment. Sloan Management Review, 39, $15-26$.

Undang-Undang Nomor 14 Tahun. (2005). Tentang Guru dan Dosen. Jakarta: Diknas.

Wernerfelt, B. (1984). A Resource Based View of the Firm. Strategic Management Journal, 5, $171-180$. https://doi.org/10.1002/smj.4250050207 
Zomorrodian, A. (2014). Strategic human capital: Approaches \& models for achieving organizational long-term competitiveness and sustainability. Proceedings of ASBBS, $21(1), \quad 754-771$. https://doi.org/10.2139/ssrn.2432515

\section{Copyrights}

Copyright for this article is retained by the author(s), with first publication rights granted to the journal.

This is an open-access article distributed under the terms and conditions of the Creative Commons Attribution license (http://creativecommons.org/licenses/by/4.0/). 